\title{
O Cinema Contemporâneo e o Regime Estético da Arte: Uma Leitura do Anticristo de Lars von Trier sob o Juízo Axiomático
}

\author{
Rodrigo Xavier*
}

\begin{abstract}
Resumo: $O$ presente texto pretende operar uma leitura do filme de Lars von Trier (Anticristo - 2009) pelo viés conceitual proposto por Jacques Rancière em A partilha do sensível. Conjugaria, pois, o filme os elementos necessários à constituição de um regime estético da arte, o que possibilita, nesse contexto, o estabelecimento de um juízo axiomático na análise do material, assim como postulado por Alain Badiou em seu Pequeno manual de inestética.
\end{abstract}

Palavras-chave: Regime estético. Juízo axiomático. Jacques Rancière. Alain Badiou. Cinema contemporâneo.

\section{Intróito}

Sergei Eisenstein afirmava em seu prefácio à obra $A$ forma do filme, que "o cinema sem dúvida, é a mais internacional das artes. [...] particularmente porque o filme, com suas ricas possibilidades técnicas e abundante invenção criativa, permite estabelecer um contato [...] com as ideias contemporâneas." (EISENSTEIN, 1957, p.11). Contudo, no mesmo texto, datado de 1946, o cineasta indaga: "a questão é o que pode ser feito no cinema, o que só pode ser criado com os meios do cinema". (Ibidem). Pertinente paradoxo elaborado por Eisenstein, é ele que move a discussão que envolve essa breve reflexão. $O$ que poderia criar o cinema na contemporaneidade que contemplasse uma apreensão do mundo da vida, ou da experiência vivida?

Essa questão remete a uma ideia de que o cinema pode assumir condição privilegiada frente às demais artes chamadas "representativas", na constituição de uma mimese como potência de pensamento, cuja identificação direta se daria na relação com os afetos programados pelo artista, imprimindo à arte uma forma sensível própria. Essa relação estabelece contato com o conceito fenomenológico da Erlebnis relação imediata entre homem-mundo, a significabilidade do vivido e o substrato não racional de seu conteúdo, ou seja, sua dimensão estética - experiência, pois, que traria resposta ao anseio poético por uma linguagem que se referisse imediatamente os sentimentos do homem, para além da fria abstração e da mera compreensibilidade entre homem e homem através de conceitos universais. Só uma linguagem que se

* Doutor em Estudos da Literatura (PUC-RIO). Professor adjunto do Departamento de Letras da UTFPR - Câmpus Pato Branco. 
baseasse nas vivências e não na consciência estaria em condições de expressar a grandeza humana. (DILTHEY, 1984).

O cinema, a priori, poderia realmente desempenhar esse papel, na condição de arte constitutiva de uma nova linguagem, assim como pensado por Jean Epstein, pois, romperia o estatuto mimético aristotélico, subvertendo a hierarquia do muthos - a racionalidade da intriga - sobre a valorização da opsis - o efeito sensível do espetáculo. Deveria o cinema não "reproduzir as coisas tais como elas se oferecem ao olhar", mas registrá-las "tais como o olho humano não as vê [...] tais como vêm a ser [...] antes de sua qualificação como objetos, pessoas ou acontecimentos identificáveis". (RANCIÈRE, 2013, p.08), já que o cinema, como postulava Gilles Deleuze, elabora em seu interior a dialética imagem-movimento versus imagemtempo, e essas duas categorias, ao contrário do que se pensava postular Deleuze, não são contraditórias entre si, mas complementares.

\section{Jacques Rancière e o regime estético da arte}

Seguindo o raciocínio engendrado até aqui, Jacques Rancière, filósofo contemporâneo francês, assim ocorre em sua percepção da literatura, vê na produção cinematográfica a constituição de um novo regime de arte, fundado no que o autor denomina de partilha do sensível. Por meio dessa operação seria possível compreender o cinema como arte que possibilita o compartilhamento entre o dizível e o visível, instaurando uma nova representatividade do real, ou constituindo um real representativo em simulacro, que nos permitiria pensar também a constituição da experiência estética em termos coletivos, na comunidade. Para o autor a arte é regida por diferentes níveis de leitura, aos quais o autor denominará "regimes". Nestes regimes, arte e política pertencem ao mesmo espaço constitutivo da sociedade. A partir disso, estabelecem-se três modos de ver a arte sob o ponto de vista de uma nova concepção espaço-temporal: um primeiro regime dito ético, um outro ao qual se chamaria poético e, por último, aquele que se reconhecerá por estético, que para o escritor é o regime do cinema por excelência.

[...] Do regime ético das imagens se separa o regime poético - ou representativo das artes. Este identifica o fato da arte - ou antes, das artes - nos par poiesis/mímesis. [...] A esse regime representativo, contrapõe-se o regime das artes que denomino estético. Estético, porque a identificação da arte, nele, não se faz mais por uma distinção no interior das maneiras de fazer, mas pela distinção de um modo de ser sensível próprio aos produtos da arte. (RANCIÈRE, 2005, p. 2833).

Rancière põe em diálogo a estética e a política, numa tentativa de perceber a qual destes regimes pertenceria o cinema contemporâneo. Poder-se-ia dizer que o cinema possibilita a leitura de um espaço intermediário entre o dizível e o visível, criando uma nova maneira de se pensar o binômio sensação/percepção, partindo da validação do regime estético. Ou seja, quando uma cena é percebida, plasmada na tela cinematográfica, concorrem inicialmente nessa imagem duas variantes: o olho do 
cineasta, e o olho da câmera. O olho do cineasta, dinâmico, não tem nenhum domínio sobre o olho da câmera, estático. Aquilo que é captado na sua materialidade instantânea e fugidia, aquele tempo materializado no movimento dos corpos constituídos na captura das imagens, serve à lente que capta, de maneira pura aquela cena, para depois, na edição, na montagem, ganhar os contornos da narrativa pelo olhar dinâmico daquele que dirigiu o olhar da câmera. Contudo, a substancialidade vívida dessas imagens, ora capturadas e redimensionadas, ao serem captadas pelo espectador, numa atitude de imprimir-lhes sentido e tornar-lhes cognoscíveis, vai perdendo paulatinamente o seu caráter de sensação pura, a partir na entrada da percepção e da tentativa de estabelecimento de um sentido inteligível neste concurso. Daí a necessidade de instauração de um novo regime das artes, que reavalie os direcionamentos desses modos de representar a experiência humana.

\section{Alain Badiou e o juízo axiomático}

Outro teórico que também pensou a anteriormente mencionada crise dos regimes representativos da arte foi o também francês Alain Badiou. Em seus escritos, Badiou levanta a discussão sobre da crítica cinematográfica na contemporaneidade. Refere-se a um papel da crítica pautado também por uma nova forma de ver, abrindo um caminho interessante para se pensar qual seria o papel da arte desempenhado na tela da sétima arte, que pode ser caracterizado por um ato discursivo que não se refere a um objeto enunciado, mas à verdade de um sujeito em constante enunciação.

Ao refletir sobre essa relação conceitual entre o representado e o representável, o sentido e o percebido, propõe o termo 'inestética' para denominar a relação entre filosofia e arte, onde esta é entendida como produtora de verdades e, portanto, não deveria ser devedora à filosofia para obter chancelamento dessas verdades, tampouco faz desta um objeto seu. Desse modo, uma obra deve ser pensada em sua singularidade, valorizando seu acontecimento em detrimento de sua estrutura, embora uma verdade que esteja pautada mais na tradução do acontecimento e sua síntese com ela mesma não passe de, nas palavras do autor "auto-revelação relativa ao acontecimento dela mesma". (BADIOU, 2002, p. 13).

Badiou anuncia a problematização do espaço de discussão filosófica no ambiente pós-moderno, uma vez que a própria filosofia pressupõe certos componentes de seu próprio desejo, como uma certa revolta contra aquilo que está instaurado, o que nos faz ficar parados, satisfeitos; o desejo de uma razão coerente, representada por um pensamento lógico; a negação daquilo que é fechado ao diálogo, opondo o particular ao universal; o engajamento e o risco, representados pelo gosto pelo encontro e pelo acaso, ou seja, a aposta.

O autor afirma que esta discussão filosófica, no presente, se faz infrutífera uma vez que o mundo parece negar o discurso filosófico, já que desacredita nos alicerces de uma concepção filosófica, quer porque o mundo da vida não oferece nenhuma perspectiva de revolta, pois que crê na ordem e na gestão natural das coisas, quer porque a nossa ordem está submetida à comunicação e às imagens, contexto no qual as opiniões são extremamente móveis e frágeis, porque a nossa única universalidade é 
a econômica, baseada na defesa de nossa própria individualidade, portanto, programando cada sujeito para projetar seu futuro o quanto antes, primando pela segurança e pelo cálculo antecipado do que virá a acontecer.

Essa certa impossibilidade de discussão, ou pelo menos, um certo desencorajamento de se pensar filosoficamente a arte, faz com que se produza uma nova tangencial para se pensar o problema.

Ao dissertar especificamente sobre a crítica cinematográfica livre dos paradigmas utilizados para as demais artes, Alain Badiou aponta para a necessidade de que sejam abandonados tanto o postulado de um juízo indistinto acerca do filme, juízo do gosto "é bom" - que situa o filme num patamar entre prazer e o esquecimento - como o postulado de um juízo diacrítico, uma espécie de incorporação, de interpretação privilegiada em relação ao simples juízo indistinto, substituindo o "é bom!", por "é superior!" - juízo que definiria uma forma "sofisticada ou diferencial da opinião comum" (BADIOU, 2002, p. 110). Segundo o autor é necessário que se encontre uma terceira maneira para se ler um filme, e propõe para isso a tomada de um juízo axiomático. Já que o filme se constitui como a visitação de uma passagem, ou seja, é tão somente seu movimento o móbile da elaboração cinematográfica, tratá-lo axiomaticamente é examinar os resultados do modo como a Ideia (no sentido platônico) é tratada pelo filme.

Explico. Nesse ponto há aparentemente um encontro entre o pensamento de Rancière e Badiou, pois as tomadas de posição que privilegiam um regime estético da arte encontram reverberação na elaboração de um juízo axiomático. As políticas estéticas contemporâneas devem apontar para novas percepções do olhar com relação às obras cinematográficas, e talvez esse novo posicionamento compreenda uma atitude fenomenológica em detrimento da busca de uma essência do evento-filme, propondo assim uma visagem destituída de um ethos concebido aprioristicamente, o que parece colocar em diálogo o entendimento de Jacques Rancière e Alain Badiou.

Temos enfim a questão que pauta esta discussão. Pensar o cinema entre o dizível e o visível, entre o sujeito que enuncia e que é enunciado no cinema é pensar um cinema que se abandona para encontrar novas verdades.

\section{O diálogo entre regime estético e juízo axiomático em Anticristo, de Lars von Trier}

Jean-Luc Godard certa feita afirmou que o cinema é a verdade 24 quadros por segundo. Há disponível uma vasta literatura que propõe diversificadas análises relacionando autores, diretores e películas na tentativa de explicitar modos e linguagens que buscaram dar conta dessa verdade plasmada no rolo de filme. Em Deleuze, por exemplo, no hall dos eleitos a grandes cineastas da história, que figuram em sua obra $A$ imagem-tempo, estão o próprio Godard, além de Roberto Rossellini, Robert Bresson, Frederico Fellini, Luchino Visconti, Sergeï Eisenstein e Orson Welles, entre outros. Mas como o foco dessa leitura privilegia um olhar contemporâneo às teorias sobre o cinema, a escolha do objeto para explicitação dessa teoria também recai sobre um diretor e uma obra mais recentes na história do cinema. O autor é o escandinavo Lars von Trier, e a obra Anticristo, lançada no Brasil em 2009. 
Já pertencente ao main stream cinematográfico, Lars von Trier é conhecido por realizar uma leitura crítica dos clichês da cultura contemporânea em sua própria cinematografia. Von Trier frequentemente recorre à tradição da tragédia, do melodrama e do musical não apenas como mero efeito estilístico, mas como estratégia para realizar um jogo reflexivo. Promovendo, a cada filme, o movimento duplo de continuidade e ruptura com as convenções, pode-se observar como o cineasta herda a tradição do cinema moderno e apresenta em seu estilo cinematográfico profundas afinidades com o também dinamarquês Carl Th. Dreyer, em sua busca por criar vida na tela. Em $O$ Anticristo, o cineasta atinge um ponto máximo daquilo que anteriormente foi denominado neste trabalho de partilha do sensível, condição para que se instaure o regime estético da arte.

Aparentemente, toda a construção de $O$ Anticristo se alicerça por meio de uma narrativa que incorpora os elementos do trágico grego, à maneira de uma opereta barroca, num processo de escritura das imagens que segue um modus operandi convencionalmente cronológico, no qual a sequência dos acontecimentos deveria, pois, revelar o estrato narrativo cujo enredo se fundamenta na perda, no sofrimento (e na sua possível superação), o que acarretaria na inevitável catarse do espectador frente à dramaticidade da história de luto vivida pelos protagonistas interpretados por Willem Dafoe e Charlotte Gainsbourg. Os nomes das personagens em nenhum momento são citados.

O filme é divido em atos: Prólogo, Luto, Dor (O Caos Reina), Desespero (Feminicídio), Os Três Mendigos e Epílogo. Essa estrutura, com aparência de organização, está assim disposta de modo que soe ao espectador como uma arquitetura dos planos da narrativa. Contudo, o que importa perceber em termos de regime estético da arte é que nessa arquitetura, embora ofereça algumas marcas cronológicas e espaciais das sequências dos acontecimentos, são as imagens, planos, música, montagem, som e fotografia - e não a estrutura externa ao evento filme que constituem em si mesmos o motor da trama, muito mais do que o conflito provocado pela perda do filho, psicanaliticamente o leitmotiv da obra. Todavia, do ponto de vista de uma leitura que privilegia o regime estético da arte, esse leitmotiv passa a fazer parte do que é externo a toda arquitetura do movimento e do tempo no filme, pois não é sobre ele que repousa a importância cinematográfica da obra.

\subsection{Prólogo}

Na primeira cena do filme, estamos diante da conjunção entre imagem e música, que constituem - independentemente do conhecimento do espectador da obra em questão - um quadro caricato da relação entre prazer, felicidade, pureza, luxúria, inocência, compromisso. Fica claro que os elementos que compõem a cena podem remeter a uma análise freudiana dos acontecimentos: Eros e Tanatos presentes respectivamente na representação de clímax do casal durante a relação sexual que se consuma no mesmo instante em que o filho encontra a morte Esses elementos conceituais são imediatamente convocados ao diálogo a partir da elaboração de um prólogo construído pela montagem de cenas consecutivas em preto e branco, que 
alternam a lascívia do casal protagonista, em oposição à pureza e ingenuidade do filho, prestes a se lançar pela janela do quarto, na tentativa de se agarrar a um bicho de pelúcia. Há um envolvimento imediato da atenção do espectador pela estimulação dos afetos convocados pela música a dialogar com as imagens. A música, neste contexto, toma vulto de mediação entre a composição fotográfica da cena - a imagem-movimento em slow motion (sob pena de parecer um tanto caricata) - e o que Arthur Schopenhauer em O Mundo como Vontade e Representação conferiu à música como arte possuidora de um estatuto privilegiado perante as outras artes ao defini-la como representação direta da essência do mundo, linguagem metafísica por excelência.

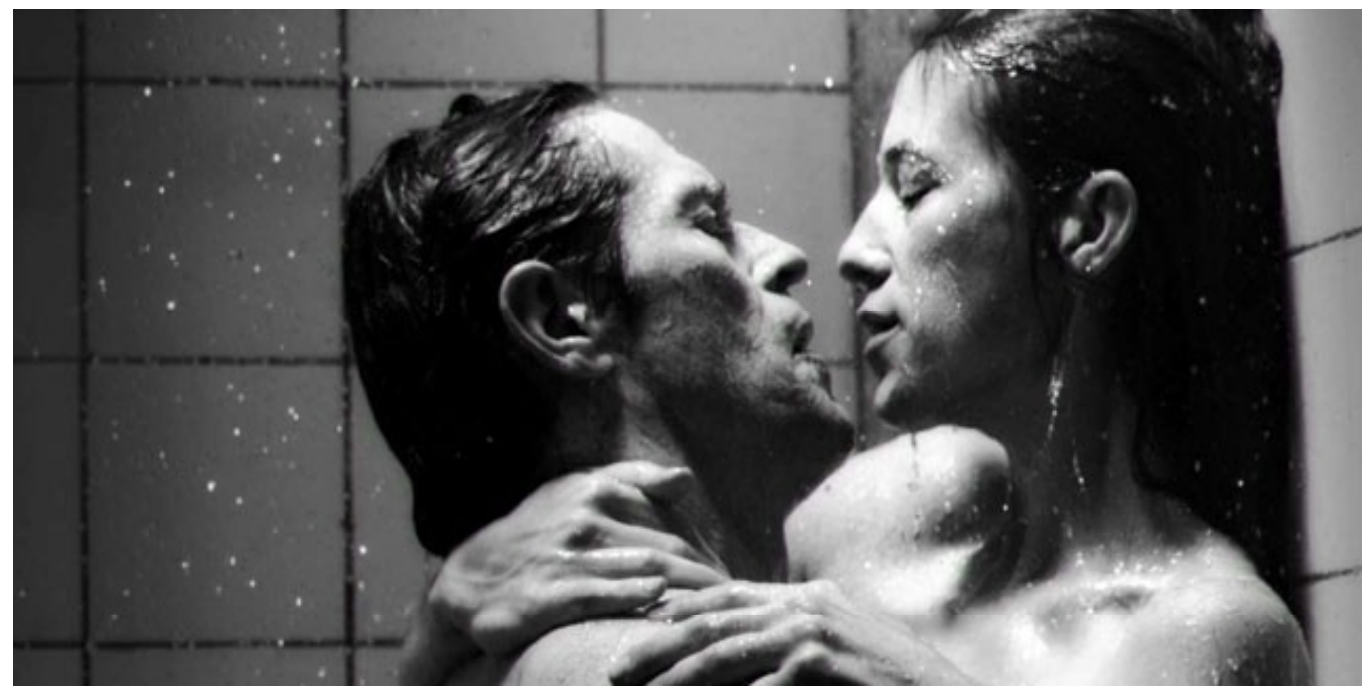

Willem Dafoe e Charlotte Gainsbourg: prazer em preto e branco

Ao convocar a música a dialogar com as imagens do prólogo, além da instauração do regime estético da arte que se consolida a partir do momento que não precisa lançar mão de um fora para dar sentido à linguagem desse instante quadro a quadro, afirma Lars Von Trier o caráter de multiplicidade evocado pela partilha do sensível. Se nos remetermos à obra utilizada para a promoção desse diálogo, perceberemos que não é gratuita a sua escolha. A música não fora convocada apenas para funcionar como um emulador da sequência de quadros, mas para instaurar um regime estético no qual a sensação de envolvimento se estabelece pela perfeita identificação entre ela e a imagem, convocando por meio dessa conjunção as sensações que somente a posteriori passarão pelo processo de racionalização.

As cenas em preto e branco se sucedem em uma espécie de epipfania, enquanto escutamos a delicadeza de uma soprano entoando uma ária barroca intitulada Rinaldo (1711), na qual seu compositor, George Friedrich Handel, lança mão da história que se passa durante a Primeira Cruzada (1096-99) e o cerco de Jerusalém. Os exércitos cristãos, liderados pelo general Goffredo, sitiam Jerusalém, então sob o domínio do rei muçulmano Argante. Este é apoiado por Armida, rainha de Damasco e poderosa feiticeira. Rinaldo, cavaleiro-herói cristão, é então procurado pelo general, que Ihe 
pede ajuda na conquista de Jerusalém. Em troca, o general Ihe oferece a mão de sua filha Almirena, que já está apaixonada por Rinaldo. A luta é travada não somente no âmbito terreno, mas também no espiritual. No final, os exércitos cristãos acabam alcançando a vitória e o bem triunfa sobre o mal. O amor terreno se contrapõe a questões mais espirituais e profundas.

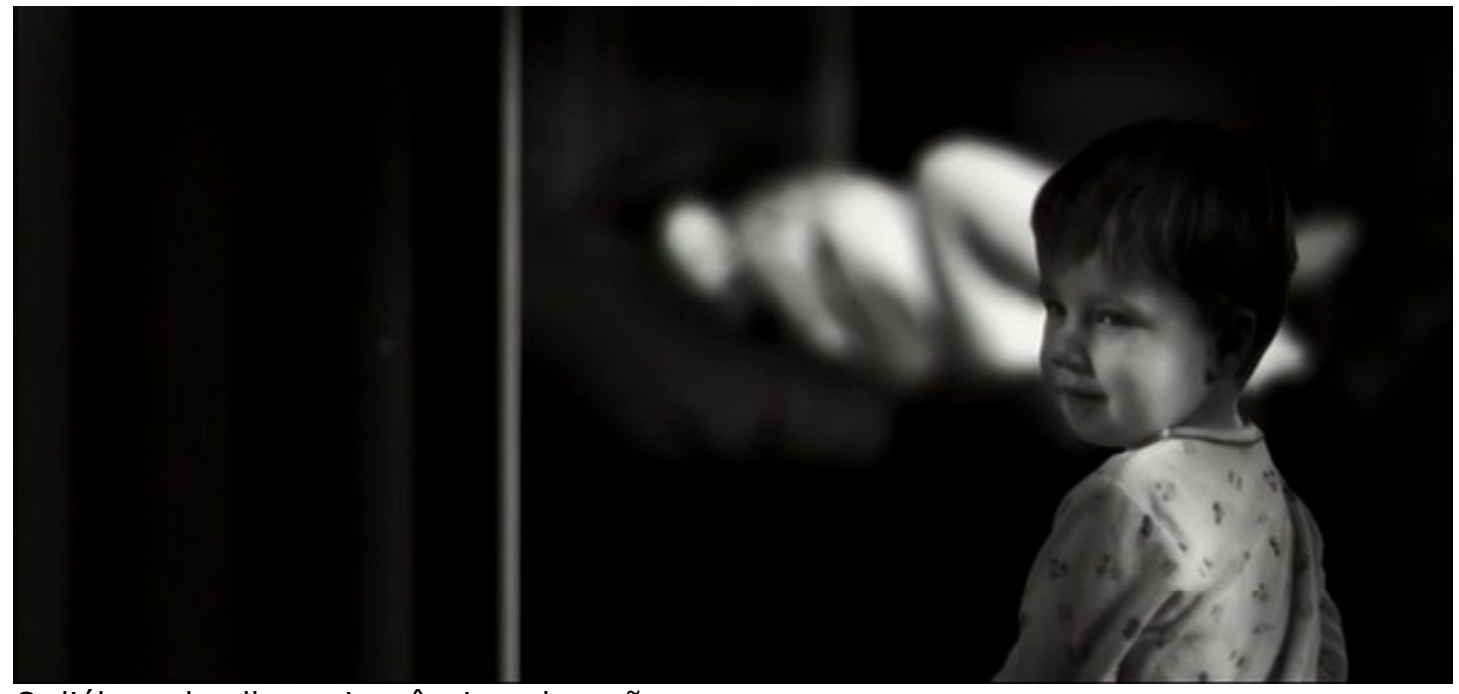

O diálogo do olhar - inocência e danação

O prólogo anuncia por meio da plasticidade de sua montagem também a opereta trágica que se desenrolará nos demais atos. A protagonista, que também estudara o período medievo para a escritura de sua tese sobre o feminicídio, entregar-se-á a uma luta interior de castração que a leva constantemente a uma literatumorfização diante do tema da tese, assumindo um papel que a aproxima daquela feitiçaria pesquisada, instaurando em seu interior uma crise entre o real e fictício, o que Ihe confere inclusive uma certa dificuldade em cumprir com o papel maternal. Isso fica claro também no prólogo, já que a preocupação com o próprio gozo também será antagonista na casuística acerca da morte do filho.

\subsubsection{Luto}

Todo o processo de luto da mulher é registrado em antagonismo com o processo no homem. As imagens que remetem ao momento posterior à perda do filho denotam o profundo vazio existencial materno, registrado pela direção do escandinavo com requintes nauseantes de um desespero em carne, veias e sombras. Os closes da lente são turvos, remetendo-nos à sensação de vertigem e pânico enfrentada pela protagonista na perda do filho. Com a exceção do primeiro minuto dessa segunda parte, cuja cena está construída pelo acompanhamento do féretro, não há tomadas externas nestes quadros que compõem o Luto, ficando toda ação restrita primeiramente ao quarto de hospital e, na sequência, ao ambiente do quarto do casal. 


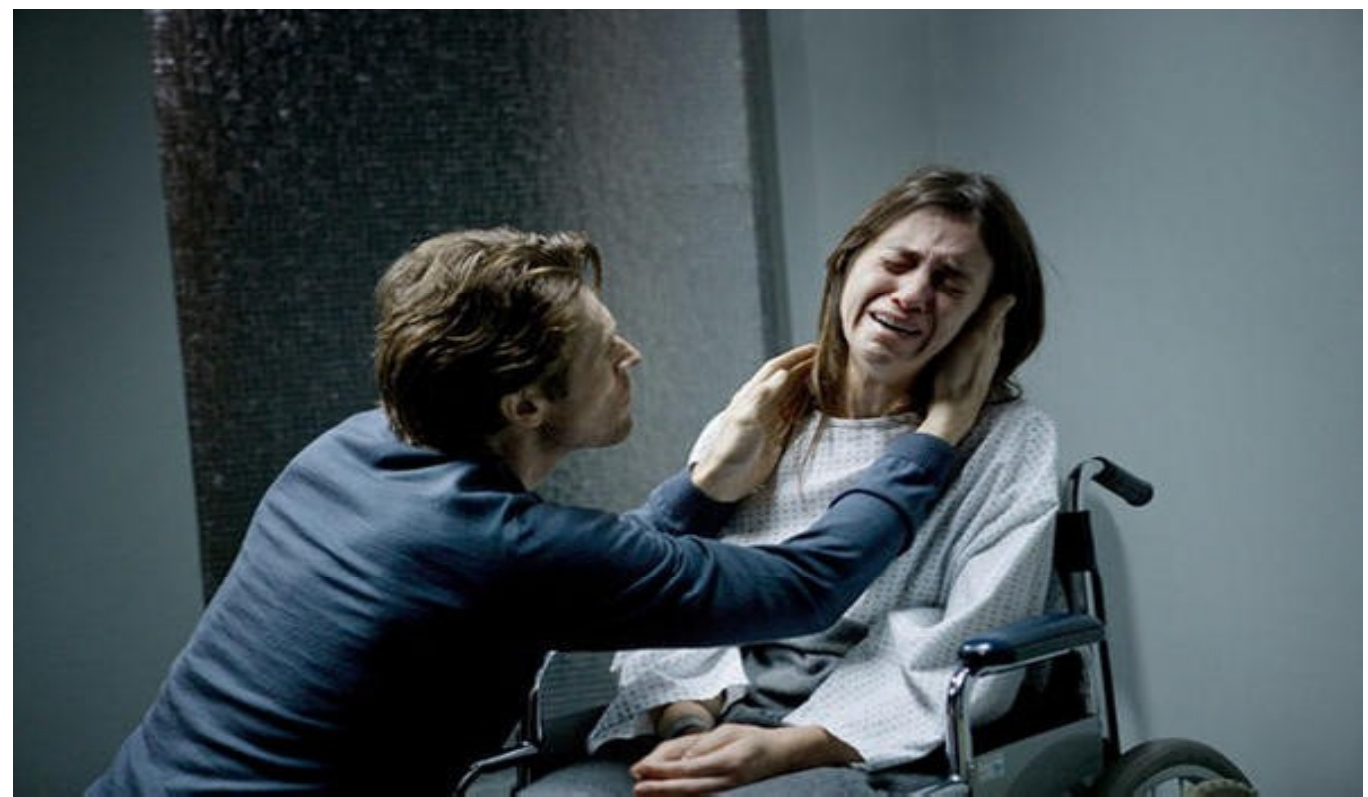

O luto e a tentativa terapêutica

A continuidade da sequência (que dura aproximadamente dezesseis minutos) convoca o espectador a vivenciar o luto com a personagem de Charlotte Gainsbourg, quer pelo tratamento dado às imagens desfocadas em close, em associação a uma terrificante arritmia respiratória, quer pelas imagens de seu suposto inconsciente, evocadas pela tentativa de hipnose terapêutica operada pelo marido psicanalista, nas quais aparece justamente a floresta, local para o qual se dirige o casal, e no qual a personagem costumava instalar-se para escrever sua tese sobre o feminicídio. A história do feminicídio na Idade Média, tema da tese da mãe em luto, confunde-se à sua história particular. O retorno ao local da escritura confere um encontro subjetivo simultâneo, no interior do qual a verdade se apresenta como um elemento dialógico na relação entre a fantasia e as alucinações provocadas pela perda do filho, a significação dessa perda para a elaboração de novas realidades a partir do evento, a relação entre a maternidade e a dedicação intelectual à tese, bem como a incorporação da história do feminicídio à ficção, à medida que a personagem entra em simbiose com o assunto pesquisado. Movimentos duplos de uma operação que põe em jogo realidade e ficção. Opera $O$ Anticristo nesse sentido o que Rancière denomina a articulação entre 0 realismo e o artificialismo, na qual o cinema toma o lugar da literatura. Cito:

Essa articulação passou da literatura para a nova arte da narrativa: o cinema. Este eleva a sua maior potência o duplo expediente da impressão muda que fala e da montagem que calcula as potências de significância e os valores de verdade. [...] $O$ real precisa ser ficcionado para ser pensado. [...] Escrever a história e escrever histórias pertencem a um mesmo regime de verdade. (RANCIÈRE, 2005, p. 57-58).

O reencontro com a cabana em meio à natureza constituirá esse retorno a si mesma, na tentativa de reencontrar o equilíbrio emocional desejado pelo marido como terapeuta. Todavia, esse equilíbrio parece ficar cada vez mais distante porque, de maneira inversamente proporcional, toda a sequência leva o espectador a 
experimentar o início do desiquilíbrio da personagem de Willem Dafoe, provocada justamente por essa relação que ele começa a estabelecer com a mãe natureza que, ao contrário do equilíbrio, marca na sequência da película a introdução do capítulo dois (segundo ato), Dor: O Caos reina. Há uma fala da personagem feminina que é contundente em relação ao papel que os elementos dentro do filme passarão a figurar arquetipicamente com intensidade cada vez mais crescente: "A natureza é a igreja do Diabo". É nesta igreja que o regime estético será definitivamente dimensionado.

\subsection{Dor (O caos reina)}

Quando se iniciam os capítulos título desta seção, percebe-se que, de fato, o cineasta dinamarquês põe em cena figurações simbólicas arquetípicas universais para que elas estabeleçam um diálogo personificado entre a questão da ficcionalidade e da realidade, ainda remetendo à significação estabelecida por Rancière no capítulo anterior. A aparição do cervo (fêmea), do corvo e da raposa é constituinte fundamental deste diálogo.

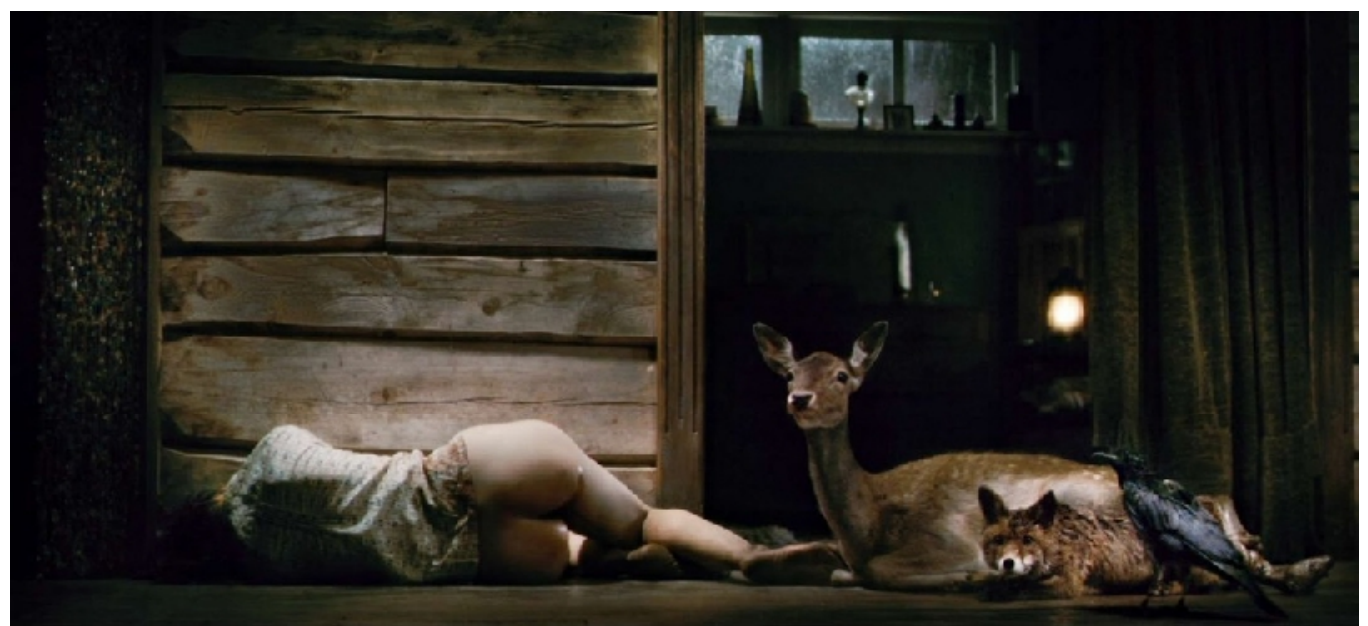

Charlotte Gainsbourg acompanhada pelos três mendigos: prenúncio do caos

Nos sonhos dos homens, a cerva simboliza a animalidade em seu aspecto mais indiferenciado, primitivo e instintivo. Já nos sonhos da mulher, evoca geralmente sua própria feminilidade, por vezes mal aceita, em estado também primitivo e instintivo mas não plenamente revelado, quer pela censura moral, por medo, por culpa pelas circunstâncias, por infantilismo psíquico ou complexo de inferioridade. Esse animal aparece em todo o filme a partir desse ato, e inicialmente parece alegorizar esses afetos no casal.

Mais especificamente relacionada à protagonista, a cerva traz em uma cena desse ato um filhote preso ao ventre, ratificando o binômio constituído pela relação da mulher com os elementos da natureza e os elementos da história presentes na sua tese. É nessa relação de aparente polarização entre o mundo da vida e o mundo ficcional estudado pela mulher que também é estabelecido o regime estético da arte. 
Levando-se em consideração que toda a figuração da mulher na idade média é revisitada pela personagem a fim de compreender a si mesma em determinada fase de sua vida, na qual o sentido se perde pela ausência do ente querido, por outras questões que levantaremos a seguir, essa incursão provoca um turbilhão de sentimentos desconhecidos na mãe. No seu retorno à cabana, ela reencontra sua feminilidade castradora, também simbolizada na cerva, no contato com uma identidade abandonada, pois também em sua aparição a cerva traz preso em si um feto natimorto e é designada (vide as constelações) como sofrimento. Seu oposto masculino, o cervo, seu duplo, simboliza por sua vez os ciclos de renovação da vida, fecundidade, crescimento, amadurecimento e todo movimento cíclico de renovação, o qual não se pode ignorar também na constituição do diálogo entre o casal, já que todos esses elementos presentes como arquétipos dizem respeito a ambos, cada um em sua potencia de alegorização.

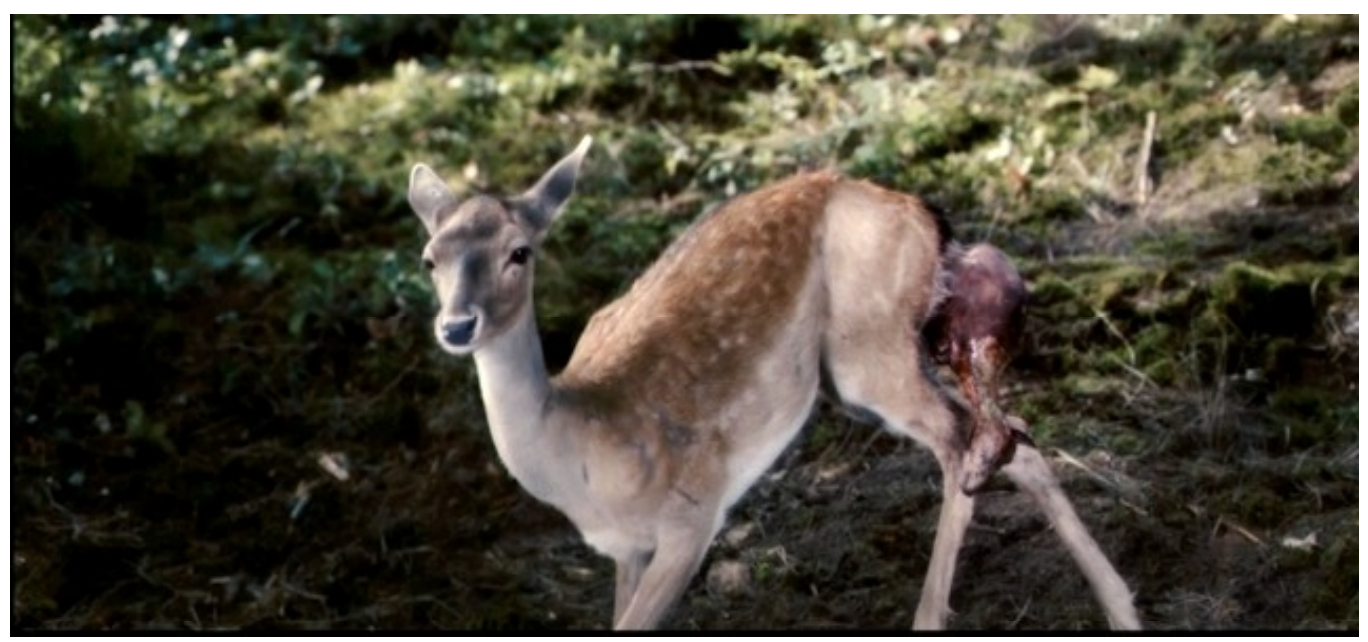

A cerva e o neófito: dor

Já, no caso do corvo, a ave na mitologia céltica era associada à morte, à guerra, à magia. O corvo está sempre presente nas batalhas, alimentando-se dos guerreiros mortos, o que simbolizava para os nórdicos o ceifador que levaria a Odin os escolhidos. (CHEVALIER, 1986, p.390). Nesta mitologia, o corvo, então, simboliza aquele que carregará a alma dos mortos para o além. Pelo viés cultural, o preto simboliza a escuridão, ou seja, aquilo que é velado. A partir deste pressuposto pode apontar para a ideia de pecado, de mal, de má sorte. Durante a idade média, por exemplo, para esconderem-se da inquisição as bruxas realizavam suas práticas durante a noite. Na visão ocidentalizada de bruxas, observamos mulheres trajadas em negro, utilizando galinhas pretas, elementos escuros, gatos pretos. No poema de Edgar Allan Poe, retomamos a passagem em que o eu lírico se remete à ave:

"Prophet!" said I, "thing of evil - prophet still, if bird or devil!

By that heaven that bends above us - by that God we both adore

-Tell this soul with sorrow laden, if, within the distant Aidenn, 
It shall clasp a sainted maiden, whom the angels name Lenore Clasp a rare and radiant maiden, whom the angels name Lenore? $(P O E, 2012, \text { p.63) })^{1}$

O corvo, aproximado ao representante do demônio, é indagado como prenunciador do mal ou da possível esperança do eu lírico se perder definitivamente nas trevas ou encontrar sua Lenore. No filme, pode-se aventar a tese de que a aparição do corvo com as cenas que se seguem (por exemplo, o corvo atacando e devorando um filhote de pássaro que cai do ninho e é imediatamente tomado por formigas) estabelece uma relação íntima com a morte do infante, bem como relembra à mãe em luto que a morte o "devorou", assim como ele agora faz com o filhote de pássaro também inerme. É o corvo no filme que também anuncia o esconderijo do protagonista, quando este, perseguido pela mulher, esconde-se em um buraco, no qual também está o corvo.

Completando a tríade, a raposa, embora tomada como símbolo da astúcia e da perspicácia pelas fábulas, representa em toda a mitologia oriental um animal de relação com os infernos. (CHEVALIER, 1986, p.1092). No filme, a raposa é o único animal que fala, anunciando o caos que definitivamente se instaurará. Apresenta cor bastante significativa à sua interpretação simbológica, avermelhada, lembrando fogo, nos levando a outra imagem das trevas: o inferno.

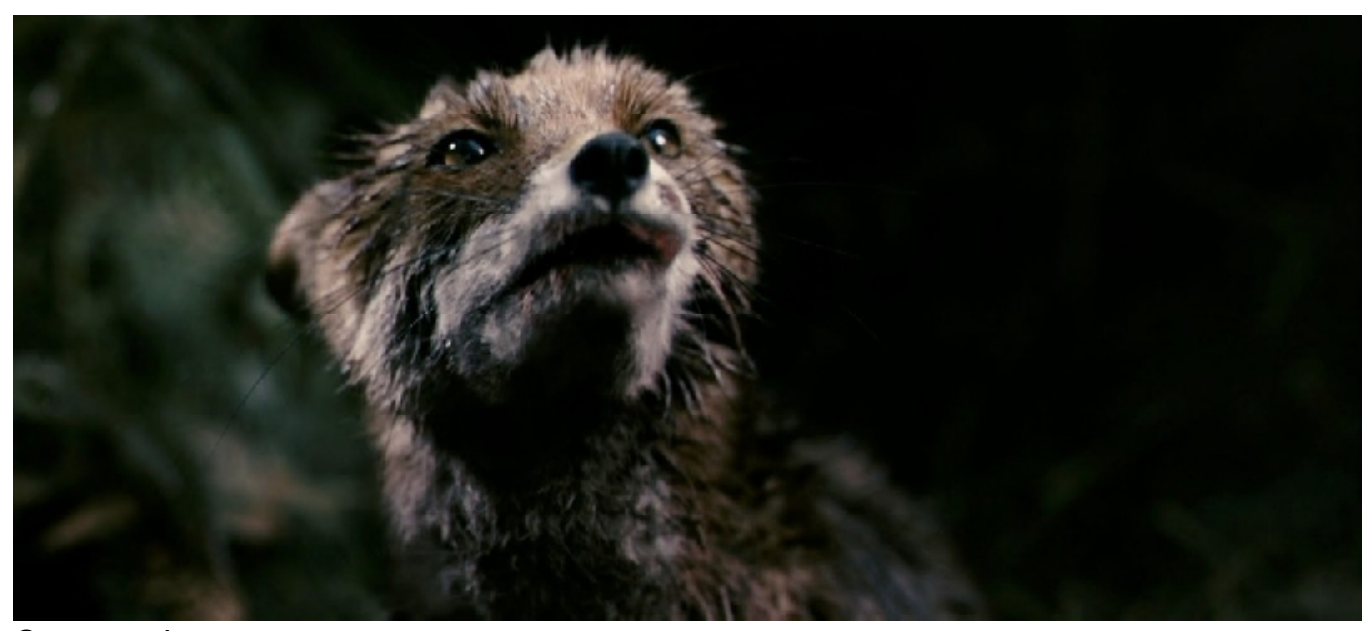

O caos reina

Os três animais são a antítese dos três magos e contribuem para a alegoria do título, mas em vez de anunciar o nascimento, é a desesperança e o feminicídio do capítulo três que realmente anunciam.

\footnotetext{
1 "Profeta", disse eu, "profeta - ou demônio ou ave preta! / Pelo Deus ante quem ambos somos fracos e mortais. / Dize a esta alma entristecida se no Éden de outra vida / Verá essa hoje perdida entre hostes celestiais, / Essa cujo nome sabem as hostes celestiais!" (Tradução de Fernando Pessoa)
} 


\subsection{Desesperança (feminicídio) e Os três mendigos}

Talvez os mais contundentes dos capítulos do filme, apresentam-se tanto o capítulo três como o capítulo quatro como rompimento da representação fiel à Ideia naquilo que Badiou postulava ser da ordem de um juízo axiomático. A convocação da Ideia de feminicídio pela desesperança é capturada em sua pureza inata pela lente de Von Trier. Exatamente uma espécie de perda da Ideia de feminicídio é convocada na sequência de tomadas e montagem. "Falar de um filme será muitas vezes mostrar como ele nos convoca a determinada Ideia na força de sua perda" (BADIOU, 2002, p.112). Ou seja, falar de um filme é simplesmente falar dele enquanto filme. As imagens dos capítulos falam por si.

Não há, a partir desse momento, a convocação de uma narrativa que dê conta do que se passa. Apenas os elementos se organizando de forma caótica (paradoxo aqui verificável), de modo que apenas os afetos que envolvem as personagens entram em jogo. Não há mais racionalização colocada em jogo pelo terapeuta, tampouco ações que se justifiquem para o concurso do entendimento e da compreensão do que se passara até aqui. O espectador é tomado pela dor, tristeza e desesperança, assim como prenunciava o mapa astronômico encontrado nos espólios de pesquisa da personagem.

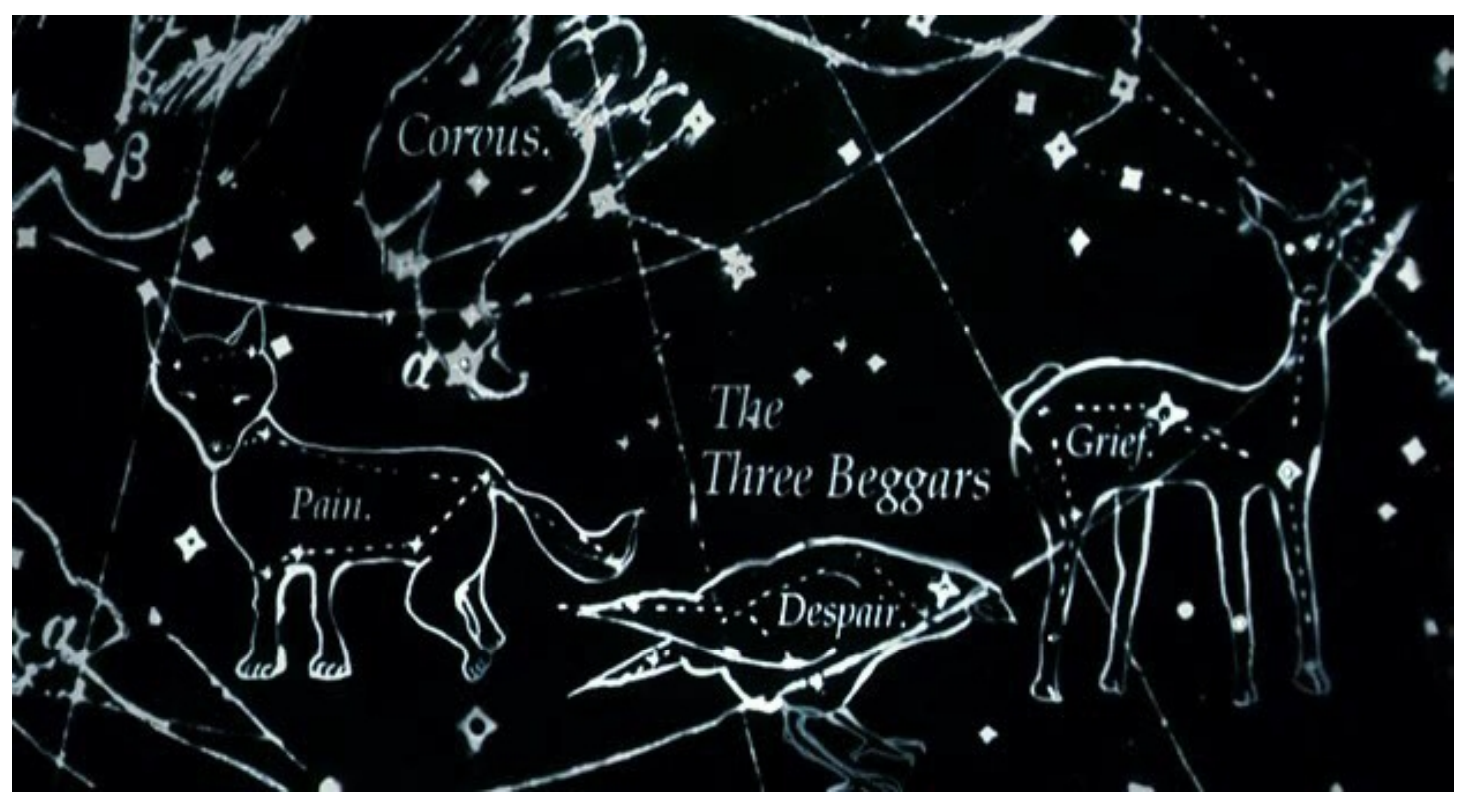

Estudos de tese: dor, desespero e tristeza

A fuga da dor, da tristeza e o abandono do desespero se dão na conjunção estabelecida na visitação da Ideia de morte como libertação, que é figurada apenas na medida em que, segundo Badiou: 
[...] há uma mistura impura dessa visitação, algo manifestadamente poético em demasia, uma suspensão que deporta a visão rumo à espera e à inquietude, em vez de nos mostrá-la em seu contorno estabelecido. Aqui, nosso pensamento não é contemplativo, ele próprio é arrebatado, viaja em companhia da Ideia, mais do que dela se apodera. (BADIOU, 2002, p.112).

\section{Epílogo}

Toda a construção da tragédia inaparentemente trágica agora, culmina no epílogo, (também nosso), no qual volta-se a cena toda à revisitação de uma mesma estética de composição do prólogo, com exceção do super slow motion. Ainda no Éden - lugar onde está construída a cabana - o encontro com a natureza se dá agora pela personagem de Dafoe, que numa espécie de ato de purgação, caminha em direção a uma multidão de rostos sem face, aparentemente tomado de surpresa por uma espécie de sensação de alívio que também toma conta do espectador. A redenção se cumpre no filme sem apelar para os sentidos externos que deveriam pois concorrer para uma análise técnica. Apenas o branco e o preto concorrendo com a ária barroca... Algo deveria ser dito? Certamente, mas a suspensão do diálogo parece se fazer necessária para que não se perca a essência.

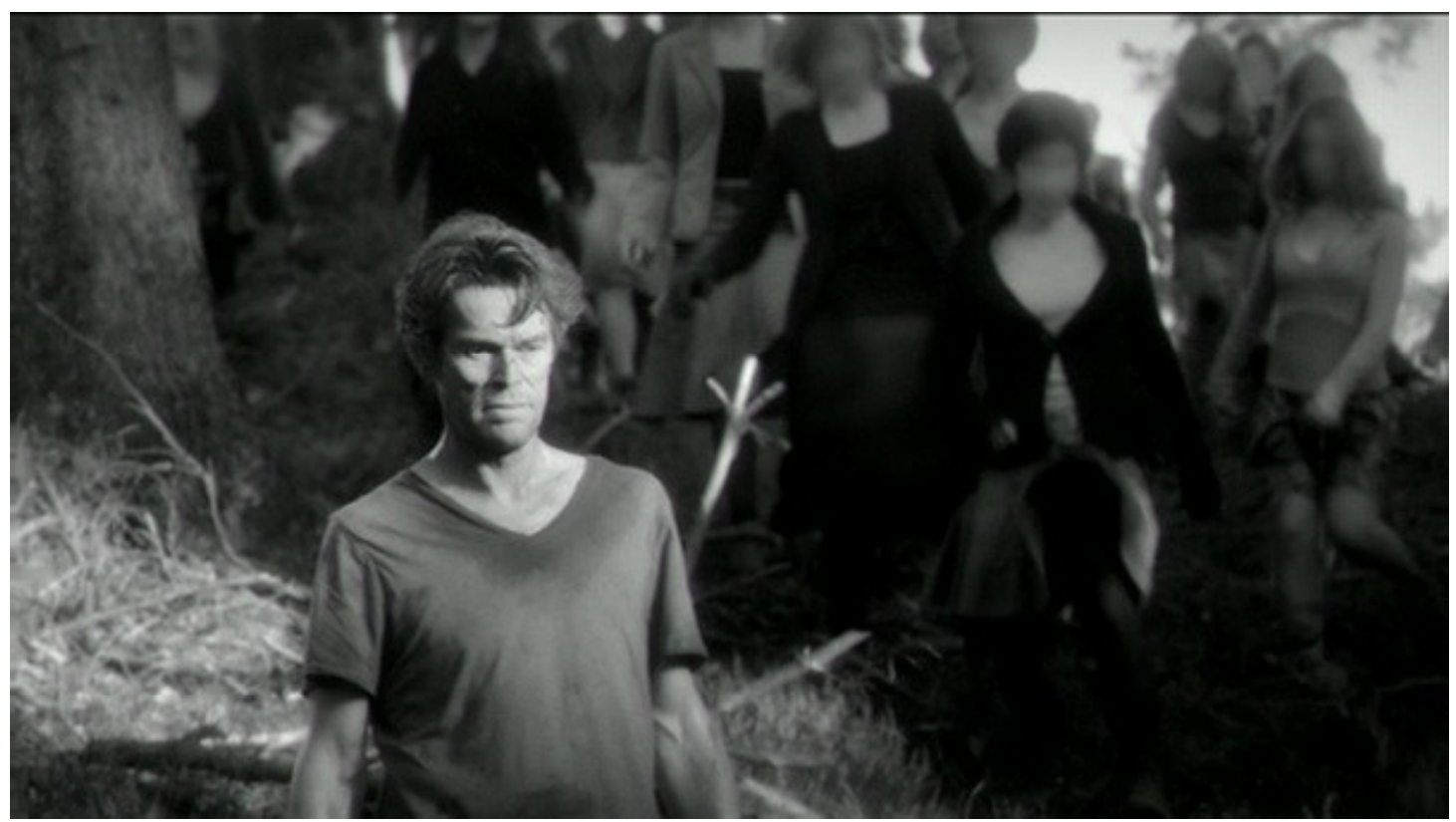

Redenção em preto e branco

Verificamos a potencia psíquica da partilha do sensível, porque é possível sentila naquele turbilhão de espectros que avançam em direção à personagem de Dafoe na cena final. Transforma-se a mimese em uma potencia de pensamento, promovendose, assim, uma identificação direta com os afetos programados pelo artista, no caso o diretor. Atinge-nos o Anticristo de maneira arrebatadora, provocando um colapso da compreensão daquele belo que se constitui numa amálgama de caos e dor. Em Lars 
von Trier parece ser possível o encontro entre o duplo da linguagem e sua materialização nas imagens que são ao mesmo tempo unidade comum do elemento ideal e do elemento sensorial. O juízo axiomático postulado por Alain Badiou se faz possível porque no Anticristo a realidade da construção de uma nova representatividade da vida em ficção associada não se opõe à carga arquetípica das fábulas e das imagens gastas dos mitos ancestrais. A arte encontra nesse espaço a possibilidade de realização de seu regime estético.

\section{Bibliografia}

O ANTICRISTO. Lars von Trier. Produção: Denmark; Germany; France; Sweden; Italy; Poland. Distribuição: Califórnia Filmes; 103 minutos; 2009.

BENJAMIN, Walter. Obras escolhidas. magia e técnica, arte e política - ensaios sobre literatura e história da cultura. Trad. bras. de Sergio Paulo Rouanet. 7. ed. São Paulo: Brasiliense, 1994;

BADIOU, Alain. Para uma nova teoria do sujeito: conferências brasileiras. Trad. de Emerson Xavier da Silva e Gilda Sodré. Rio de Janeiro: Relume Dumará, 1994;

Pequeno manual de inestética. Trad. de Marina Appenzeller. São Paulo:

Estação Liberdade, 2002;

CHEVALIER, Jean; GHEERBRANT, Alain. Diccionario de los símbolos. Barcelona: Editorial Herder, 1986.

DELEUZE, Gilles. A imagem-tempo. Trad. de Eloisa de Araújo Ribeiro. São Paulo: Brasiliense, 2007.

DILTHEY, Wilhelm. Essência da filosofia. Lisboa: Presença, 1984.

EISENSTEIN, Sergueï Mikhaïlovitch. Film form. Trad. de Jay Leyda. Cleveland: Meridian Books, 1957.

PESSOA, Fernando. O Corvo. In: BONACIN, Larissa D.; Schäffel, Dicleia Maria B. Disponível em:

http://www.utp.br/eletras/ea/eletras20/textos/Primeiros_ensaios_20.4_Traducao_poet ica_O_corvo_BONACIN_SCHAFFEL.pdf

POE, Edgar Allan. The complete works. New York: Hard Press Editions, 2012;

RANCIÈRE, Jacques . A partilha do sensível: estética e política. Trad. de Monica Costa Netto. São Paulo: EXO experimental org.; Ed. 34, 2005;

A fábula cinematográfica. Trad. de Christian Pierre Kasper. Campinas: Papirus, 2013.

SCHOPENHAUER, Arthur. O mundo como vontade e representação. Ribeirão Preto: Editora Unesp, 2005. 
Title: The Contemporary Cinema and Esthetic Regime of Art: A Reading of the Antichrist by Lars von Trier under the Axiomatic Judgment

Abstract: This paper aims to perform a reading of Lars von Trier's film - Antichrist by the conceptual bias proposed by Jacques Rancière in his book Le partage du sensible: esthétique et politique. This film would combine the elements required to constitute an esthetic regime of art, which allows, within this context, the establishment of an axiomatic sense in the material analysis, as predicated Alain Badiou in his Handbook of Inaesthetics.

Keywords: Aesthetic regime. Axiomatic judgment. Jacques Rancière. Alain Badiou. Contemporary Cinema.

Recebido em: 09/09/2013. Aceito em 30/11/2013. 